\title{
ORTHODOX REFORM IN THE POLISH-LithuANIAN COMMONWEALTH
}

\section{Liudmila Sharipova}

"Are you, the Ruthenian, not suffering from infantile reasoning, you who used to be a pious Christian ... but having lived with the Poles you became child-like and divided, abandoned Christ and split into the Papist, the Evangelical, the Anabaptist and the observer of the Sabbath?"1 Thus the monk Ivan Vishenskii (ca. 1550-1620), a selfappointed guardian of his nation's ancestral faith, chided his Orthodox compatriots and fellow-believers, writing from the spiritual heights of Mount Athos. Contrary to the prevalent opinion in contemporary historiography that the Eastern Orthodox Church remained unaffected by the spread of Protestantism in Eastern Europe, ${ }^{2}$ Vishenskii's diatribe highlights both the fears of Orthodox religious activists and the realities of the confessional situation in Poland-Lithuania at the turn of the $16^{\text {th }}$ and $17^{\text {th }}$ centuries.

I am grateful to Professor Julia Barrow, Professor Robert Frost, Dr John Haggerty and Dr Jonathan Shepard for reading earlier versions of this chapter and providing valuable comments. Thanks are also due to Professor Ronan Fanning for help and encouragement.

${ }^{1}$ Akty, otnosiashchiesia $k$ istorii Iuzhnoi i Zapadnoi Rossii, sobrannyie i izdannyie Arkheograficheskoiu komissieiu, 2 (St Petersburg, 1865), p. 220. Here the "Evangelical" is a reference to Calvinists, and the "Sabbatarian"--to Unitarians.

${ }^{2}$ See Andrew Pettegree and Karin Maag, "The Reformation in Eastern and Central Europe", The Reformation in Eastern and Central Europe, ed. Karin Maag (Aldershot, 1997), p. 12. 
To the historian of religious change in Europe in its evangelical forms, such as the German, Swiss or English Reformations, the truth of the statement that "the Orthodox churches have not experienced a Reformation" seems incontrovertible. ${ }^{3}$ Indeed, in no area of Europe, where the population was exclusively or predominantly Eastern Orthodox in the early modern period, did Protestantism become a religion of the elites or of the masses. This was not always for lack of trying on the part of secular rulers who at times adopted new religious teaching and wished to impose it on their subjects. ${ }^{4}$ Yet those scholars whose expertise extends to Catholic revival in the $16^{\text {th }}$ and $17^{\text {th }}$ centuries should think twice before dismissing the Orthodox Church as a potential area of research into the processes of religious renewal in the Confessional Age.

Linguistic barriers, political dislocations of the twentieth century and a fragmentation of vision attendant on narrow historical specialisations have conspired to obscure the attempts within the Orthodox Church to give it a new lease of life in the atmosphere of intense confessional rivalry characteristic of the period of religious change. In the beginning, the range and availability of documentary evidence largely determined the historiographic outcomes. From the 1840s to the start of the First World War, learned associations in the Imperial Russia, such as the national and regional Commissions for the Study of Archaeography (arkheograficheskie komissii), undertook a series of large-scale publishing projects, aimed to make widely available a bulk of

\footnotetext{
${ }^{3}$ Diarmaid MacCulloch, Reformation: Europe's House Divided, 1490-1700 (London, 2003), p. xx.

${ }^{4}$ See Maria Crăciun, "Protestantism and Orthodoxy in 16"-Century Moldavia", The Reformation in Eastern and Central Europe, pp. 126-135.
} 
documentary materials from the late medieval and early modern periods. ${ }^{5}$ Despite an occasionally tendentious selection of documents, for example, by suppressing the material that could belie Imperial Russia's "historic claim" to its western borderlands against the counter-claims of Polish nationalists, ${ }^{6}$ this was a pivotal development that gave momentum to subsequent conceptualisation of the history of the region. By 1914 ${ }^{5}$ Akty istoricheskie, sobrannye i izdannye Arkheograficheskoiu komissieiu, 1334-1700, 5 vols (St Petersburg, 1841-1842); Dopolneniia $k$ aktam istoricheskim, sobrannye $i$ izdannye Arkheograficheskoiu komissieiu, 12 vols (St Petersburg, 1846-1872); Akty, otnosiashchiesia $\mathrm{k}$ istorii Zapadnoi Rossii, sobrannye i izdannye Arkheograficheskoiu komissieiu, 1340-1699, 5 vols (St Petersburg, 1846-1853; hereafter AZR); Akty, otnosiashchiesia $k$ istorii Iuzhnoi i Zapadnoi Rossii, sobrannye i izdannye Arkheograficheskoiu komissieiu, 1361-1699, 15 vols (St Petersburg, 1861-1892); Pamiatniki polemicheskoi literatury v Zapadnoi Rusi, 3 vols (Russkaia istoricheskaia biblioteka, izdavaemaia Arkheograficheskoiu komissieiu, vols 4, 7, and 19) (St Petersburg, 1878-1903); Pamiatniki, izdannye Vremennoiu komissieiu dlia razbora drevnikh aktov ... pri Kievskom voennom, Podol'skom i Volynskom generalgubernatore, 4 vols (Kiev, 1845-1859); Arkhiv Iugo-Zapadnoi Rossii, izdannyi Vremennoiu komissieiu dlia razbora drevnikh aktov ... pri Kievskom ... generalgubernatore, 8 parts in 35 vols (Kiev, 1859-1914; hereafter Arkhiv IuZR); Pamiatniki, izdannye Kievskoiu komissieiu dlia razbora drevnikh aktov, 3 vols (Kiev, 1897-1898); Akty, izdavaemye Komissieiu ... dlia razbora drevnikh aktov v Vil'ne, 39 vols (Vilnius, 1865-1915); Arkheograficheskii sbornik dokumentov, otnosiashchikhsia k istorii SeveroZapadnoi Rusi, izdavaemyi pri upravlenii Vilenskogo uchebnogo okruga, 14 vols (Vilnius, 1867-1904).

${ }^{6}$ M.V. Dovbyshchenko, Volyns'ka shliakhta u relihiinykh rukhakh kintsia XVI- pershö̈ polovyny XVII st. (Kiev, 2008), pp. 18-19. 
extensive publication of primary sources had enabled historians to produce a range of scholarly contributions that shed light in particular upon the effects of the spread of Protestantism on the Eastern Orthodox Church in the Commonwealth. ${ }^{7}$ Other scholars' exploration of the subject was based on unpublished sources discovered in local libraries and archival holdings. ${ }^{8}$ At the same time, the stimulus provided by Catholic reform and Counter-Reformation in Poland received extensive coverage in imperial historiography, in large part due to the lasting legacy of the Church Union of Brest. ${ }^{9}$

\footnotetext{
${ }^{7}$ Ivan Sokolov, Otnoshenie protestantizma k Rossii v XVI i XVII vekakh (Moscow, 1880), pp. 245-450; Orest Levitskii, "Sotsinianstvo v Pol'she i Iugo-Zapadnoi Rusi",
} Kievskaia starina, 2 (1882), 25-57, 193-224, 381-432; idem, "Predislovie", Arkhiv IuZR, I, 4 (Kiev, 1883), pp. 1-182; Dm. Tsvetaev, Protestantstvo i protestanty v Rossii do epokhi preobrazovanii (Moscow, 1890), pp. 512-696. For a general overview of the historiography of the Ukrainian lands in the period before the First World War see Stephen Velychenko, National History as Cultural Process: A Survey of the Interpretations of Ukraine's Past in Polish, Russian, and Ukrainian Historical Writing from the Earliest Times to 1914 (Edmonton, 1992).

${ }^{8}$ N.P. Dashkevich, “'Odin iz pamiatnikov religioznoi polemiki XVI veka (Poslanie prota Afonskoi gory 1534 goda)", Chteniia v istoricheskom Obshchestve Nestora Letopistsa (hereafter ChOINL), 15 (1901), 179-201; O.A. Fotinskii, "Volynskii religioznyi vol'nodumets XVII v.", ChOINL, 18 (1904), 71-102; S.A. Shcheglova, Virshi prazdnichnye i oblichitel'nye na arian kontsa XVI- nachala XVII V. (Pamiatniki drevnei pis'mennosti i iskusstva, 182) (S. 1., 1913).

${ }^{9}$ M. Koialovich, Litovskaia tserkovnaia uniia, 2 vols (St Petersburg, 1859-1861); M. Malinowski, O unii kościoła greko-katolickiego ruskiego (Lviv, 1862); N. BantyshKamenskii, Istoricheskoe izvestie o voznikshei v Pol'she unii (Vilnius, 1864); 
Following the interruption of regular scholarly activity in the former Russian Empire during the revolutionary period, the strait-jacket of Marxist conformity imposed on historical studies in the Soviet Union from the late 1920s made it all but impossible to conduct serious research in religious history. Although outside the country émigré ecclesiastical historians and some European scholars strove to keep alive the subject of the impact of the European Reformations on the Orthodox renewal of the sixteenth and seventeenth centuries, on the whole it remained outside the mainstream of historical debates. ${ }^{10}$ The easing of ideological restrictions and the eventual dissolution of the Soviet

A.P. Demianovich, “Iezuity v Zapadnoi Rossii (v 1569-1772 godakh)”, Zhurnal Ministerstva narodnogo prosveshcheniia, 8 (1871), 181-236, 9 (1871), 1-46, 10 (1871), 250-279, 11 (1871), 40-86, 12 (1871), 181-231; Mitropolit Makarii [Bulgakov], Istoriia russkoi tserkvi, 9 (St Petersburg, 1879), pp. 478-689, 10 (St Petersburg, 1881), pp. 238500; N.F. Sumtsov, "Istoricheskii ocherk popytok katolikov vvesti v Iuzhnuiu i Zapadnuiu Rossiiu grigorianskii kalendar”, Kievskaia starina, 21 (1888), 235-272; P. Zhukovich, Seimovaia bor'ba pravoslavnogo zapadnorusskogo dvorianstva s tserkovnoi uniei (do 1609 g.) (St Petersburg, 1901); Edward Likowski, Uniia Brzeska (Warsaw, 1907); P.G. Viktorovskii, Zapadno-russkie dvorianskie familii, otpavshie ot pravoslaviia v kontse XVI i v XVII vV. (Kiev, 1912); Wacław Lipiński, Szlachta unici: z dziejów Ukrainy (Kiev, 1912).

${ }^{10}$ Ivan Ohienko (Mytropolyt Ilarion), "Reformatsiia v Ukraïni”, idem, Ukraïns 'ka tserkva, ed. M. Tymoshyk (Kiev, 2007), pp. 167-181; Georgii Florovskii, Puti russkogo bogosloviia (Paris, 1937), pp. 30-56; J. Janów, “Tłumacyenia ruskie z 'Postylli’ M. Reja w ewangeliarzach kaznodziejskich XVI i XVII wieku”, Sprawozdania z czynności i posiedzeń Polskiej Akademii Umiejętności, 34 (1929), 2-10; Ambroise Jobert, De Luther à Mohila: la Pologne dans la crise de la Chrétienté, 1517-1648 (Paris, 1974); George 
Union enabled the historians in its emergent successor states to re-enter normal professional discourse and produce research, in which immediate access to sources could be married to up-to-date methodologies in Reformation studies, notably by Mikhail Dmitriev, Boris Floria and Serhii Plokhy. ${ }^{11}$ The next two decades witnessed the appearance of further important contributions from students of Orthodox religious history in Eastern Europe and North America. ${ }^{12}$ These significant advances notwithstanding, the

Williams, "Protestants in the Ukraine during the Period of the Polish-Lithuanian Commonwealth”, Harvard Ukrainian Studies, 2 (1978), 41-72, 184-210 (hereafter HUS).

${ }^{11}$ Mikhail Dmitriev, Pravoslavie i reformatsiia: reformatsionnye dvizheniia $v$ vostochnoslavianskikh zemliakh Rechi Pospolitoi vo vtoroi polovine XVI v. (Moscow, 1990); idem, "Culture 'latine' et culture 'orthodoxe' à l'est de l'Europe au XVIIe siècle", XVIIe siècle, 3 (2003), 391-414; idem, "Western Christianity and Eastern Orthodoxy", Reform and Expansion, 1500-1660, ed. R. Po-Chia Hsia, The Cambridge History of Christianity 6 (Cambridge, Eng., 2007), pp. 321-342; idem, "Les confréries de Ruthénie dans la deuxième moitié du XVI siècle--une 'Réforme orthodoxe'?”, Etre catholique-être orthodoxe--être protestant: Confessions et identités culturelles en Europe médiévale et moderne, eds. Marek Derwich and Michael Dmitriev (Wrocław, 2003), pp. 207-20; Boris Floria, ed., Brestskaia uniia 1596 g. i obshchestvenno-politicheskaia bor'ba na Ukraine i v Belorussii v kontse XVI- nachale XVII v., 2 vols (Moscow, 1996-1999); Serhii Plokhy, Papstvo i Ukraina: politika papskoi kurii na ukrainskikh zemliakh v XVIXVII vekakh (Kiev, 1989); idem, Cossacks and Religion in Early Modern Ukraine (Oxford, 2001).

${ }^{12}$ David A. Frick, Meletij Smotryc'kyj (Cambridge, Mass., 1995); Borys Gudziak, Crisis and Reform: the Kyivan Metropolitanate, the Patriarchate of Constantinople, and the Genesis of the Union of Brest, Harvard series in Ukrainian studies (Cambridge, Mass., 
effect on the Orthodox Church of religious changes that overtook continental Europe in the early modern period still remains peripheral to Reformation studies generally. Most importantly, the existent research leaves significant gaps in our knowledge of local and regional responses to religious change in the Orthodox lands of the Polish-Lithuanian Commonwealth, the rise of anticlericalism attendant on the heightening of religious fervour from the 1560s onward, detailed quantitative evaluations of the distribution of confessional allegiances following the split of the Orthodox Church into two Eastern Rite confessions in 1596, and the extent of social disciplining, which accompanied the process of Orthodox confession building.

This essay offers a synthesis of the interpretations of the rejuvenation of Orthodox religious life in the Polish-Lithuanian Commonwealth found in Polish, Russian, Ukrainian, North American and Western European historiography. It is informed by the author's original research into the intellectual origins of the reforms of the Metropolitanate of Kiev in the $17^{\text {th }}$ century. ${ }^{13}$ The discussion that follows will address four major points: firstly, exogenous Protestant influences on the Eastern Church,

1998); Margarita Korzo, Ukrainskaia i belorusskaia katekheticheskaia traditsiia kontsa XVI-XVIII vv.: stanovlenie, evoliutsiia i problema zaimstvovanii (Moscow, 2007); Valerii Zema, "Prychynok do pravoslavnoï polemyky doby Kontrreformatsiï", Kovcheh: naukovyi zbirnyk iz tserkovnoï istoriï, 5 (2007), 73-99; Igor Bortnik, "Problem tolerancji w prawosławnej myśli teologicznej i społeczno-politycznej w Rzeczpospolitej drugiej połowy XVI i pierwszej połowy XVII wieku”, Odrodzenie i Reformacja w Polsce, 51 (2007), 151-175; Dovbyshchenko, Volyns'ka shliakhta.

${ }^{13}$ See Liudmila V. Charipova, Latin Books and the Eastern Orthodox Clerical Elite in Kiev, 1632-1780 (Manchester, 2006). 
facilitated by the high level of constitutionally-guaranteed confessional toleration in Poland-Lithuania; secondly, the position of the Orthodox Church vis-à-vis the Eastern patriarchs, the Polish-Lithuanian state, and the relationship between the Orthodox Church hierarchy and the laity; thirdly, endogenous reforming tendencies at the grass-roots level and the response of the Orthodox episcopate to this challenge; and fourthly, the significance of the realignment of the Metropolitanate of Kiev in tune with the realities on the ground, presented by the shifting confessional situation. ${ }^{14}$ Two overlapping trends can be distinguished in the reform movement within the Orthodox Church in our period: what may be called "estates-driven" reforms (1586-1632), as against the reorganization of religious life promoted by the church hierarchy (1590-1646). The former involved townspeople and the Orthodox nobility and may be provisionally categorised as calls for a bottom-up religious change. Conversely, the legally-enshrined noble profile of the Orthodox episcopate and its reliance on the state for the realization of their reforming projects makes it possible to describe them as top-down reforms.

Confronted with new doctrinal certainties of Latin Christianity, early modern Orthodox theologians hurriedly tried to find an answer to this shift of tectonic plates. While considered in its own terms the Eastern Church could still pride itself on being unfettered by excessive regulation, contemplative and holy, to outside observers, caught up in their own struggles for confessional identity, it increasingly appeared to be obscure,

${ }^{14} \mathrm{Cf}$. the term aggiornamento (Ital., "bringing up to date") borrowed by Vittorio Peri from the era of the Second Vatican Council: Vittorio Peri, "Beresteis'ka uniia u ryms'komu bachenni", Istorychnyi kontekst ukladennia Beresteis'koï unï̈ i pershe pouniine pokolinnia: Materialy Pershykh “Beresteis 'kykh chytan”, ed. Borys Gudziak (Lviv, 1995), p. 8. 
inward-looking and moribund. Flailing about in the absence of a fixed, universally accepted Orthodox credal tradition, generations of Orthodox reformers would seek to align their dogmatic teaching with either Catholic or Protestant positions in the hope of finding a "third way" that would be generally acceptable to the Eastern Church. ${ }^{15}$

The frequency of references in Orthodox religious writings of the early modern period to the first seven ecumenical councils (325-787) is an indication of how far their decrees served to fill the gap left by the centuries of under-regulation. In a missive to the Lutheran theologians of Tübingen Patriarch Jeremiah II stated that he would say "nothing originating of ourselves, but (what is pertinent) from the holy Seven Ecumenical Synods" ${ }^{16}$ A quarter of a century later the author of a 1602 anti-Protestant pamphlet drew a direct link between the condemnation of iconomachia (the war against icons) by the Second Council of Nicaea and the rise of Evangelical belief in late mediaeval and early modern Europe.$^{17}$ The anachronistic nomenclature consistently applied to Protestant denominations in polemical treatises penned by the Orthodox labelled them "Arians",

\footnotetext{
${ }^{15}$ See David A. Frick, "Misrepresentations, Misunderstandings, and Silences: Problems of Seventeenth-Century Ruthenian and Muscovite Cultural History", Religion and Culture in Early Modern Russia and Ukraine, eds. Samuel H. Baron and Nancy Shields Kollmann (De Kalb, Ill., 1997), p. 151; Bortnik, "Problem tolerancji w prawosławnej myśli teologicznej”, p. 160.

${ }^{16}$ George Mastrantonis, ed., Augsburg and Constantinople: The Correspondence between the Tübingen Theologians and Patriarch Jeremiah II of Constantinople on the Augsburg Confession (Brookline, Mass., 1982), p. 31.

${ }^{17}$ Arkhiv IuZR, I, 8 (Kiev, 1914), pp. 69-70.
} 
"Nestorians" or "Apollinarians", and more generally as "heretics", an attribution seldom applied to Roman Catholics. ${ }^{18}$

The extract from Vishenskii's writings cited at the beginning of this essay testifies to the variety of religious creeds then extant in Ruthenia. This term, widely used in contemporary sources in its Slavic form "Rus" or its Latinized version "Ruthenia", originally described the followers of the Orthodox religion. They constituted the majority or an important minority in the eastern and north-eastern parts of the Polish-Lithuanian Commonwealth (the territory roughly coinciding with modern-day Ukraine and Belarus). ${ }^{19}$ The adoption of the principle of religious toleration for the noble nation of Poland-Lithuania under the 1573 Confederation of Warsaw turned the Commonwealth into a safe haven for a multitude of Protestant trends, including those of a radical nature persecuted elsewhere in Europe, such as the Anabaptists and the Unitarians (Antitrinitarians). ${ }^{20}$ Contrasted with the set ways and frequently low level of education displayed by Orthodox clergy, Protestant fervency of belief and intellectual appeal

${ }^{18}$ See, for example, Pamiatniki polemicheskoi literatury v Zapadnoi Rusi (Russkaia istoricheskaia biblioteka 7), 2 (St Petersburg, 1882), col. 936; Shcheglova, Virshi prazdnichnye i oblichitel'nye na arian, pp. 102-103, 105, 109-11; Arkhiv IuZR, I, 8, pp. $18,47$.

${ }^{19}$ The term may also be applied to the same geographical area by extension. This meaning is distinct, however, from that of the Palatinate of Ruthenia or Red Ruthenia, the area that became known as Eastern Galicia following the partitions of Poland.

${ }^{20}$ On the Confederation of Warsaw see Andzhei Sulyma Kamins'kyi, Istoriia Rechi Pospolytoï iak istoriia bahatiokh narodiv, 1505-1795: Hromadiany, ikhnia derzhava, suspil'stvo, kul'tura (Kiev, 2011), pp. 68-69. 
exerted a powerful attraction upon many Orthodox nobles. The new religion also held the promise of relieving them from clerical domination and promoting noble leadership in church affairs. ${ }^{21}$ A number of prominent Orthodox noble families converted to Calvinism and Unitarianism in the 1560s. Other magnates, such as the eminent patron of Orthodox religion and culture Prince Constantine Ostrozskii (1526-1608) showed an interest in Evangelical teaching and extended their patronage to Protestant scholars. ${ }^{22}$ Following the 1569 Union of Lublin, which permanently brought the Kingdom of Poland and the Grand Duchy of Lithuania under the same political authority, while allowing the latter to retain broad autonomous powers, there were nearly 400 Protestant congregations, mostly Unitarian, in Ruthenia. ${ }^{23}$ A Catholic polemicist argued that in the Navahrudak region of Lithuania, only sixteen out of about 600 Orthodox noble families had managed to resist

${ }^{21}$ Ohienko, "Katolyts'ka reaktsiia”, idem, Ukraïns'ka tserkva, p. 184; Bortnik, "Problem tolerancji w prawosławnej myśli teologicznej”, p. 162.

${ }^{22}$ Orest Levitskii, “Sotsinianstvo v Pol'she i Iugo-Zapadnoi Rusi”, pp. 29, 38; Ohienko, “Reformatsiia v Pol'shchi”, idem, Ukraïns'ka tserkva, pp. 174-75; Dovbyshchenko, Volyns'ka shliakhta, pp. 403-405, 409-13.

${ }^{23}$ Williams, "Protestants in the Ukraine", p. 42. Cf. the report of the Jesuit Antonio Possevino that on his visit to Transylvania, another region of East-Central Europe where diverse Evangelical beliefs flourished in conditions of broad confessional freedom, in 1584 he "found approximately 500 Protestant preachers ... of whom 200 were Calvinist, 200 Lutheran and 100 Unitarian”: Joachim Bahlcke, "Calvinism and Estate Liberation Movements in Bohemia and Hungary (1570-1620)", The Reformation in Eastern and Central Europe, ed. Maag, p. 78. On the Union of Lublin see Harry E. Dembkowski, The Union of Lublin: Polish Federalism in the Golden Age (East European Monographs 66) (New York, 1982); Kamins’kyi, Istoriia Rechi Pospolytoï, pp. 55-65. 
Evangelical proselytizing. ${ }^{24}$ Even allowing for the inevitable exaggeration, the impact of Protestantism is impossible to overlook. Under the terms of the Warsaw Confederation, a lord who converted to another religion had the right to demand that the population living on his estates followed suit. ${ }^{25}$ Noble conversions, therefore, could have broader social consequences.

If the increasing availability of Protestant biblical translations into the universally accessible Polish language was worrying, the appearance of the Bible and printed Protestant catechisms in Ruthenian was an unambiguous sign of Evangelical proselytizing aimed at Orthodox audiences. ${ }^{26}$ Such apprehensions were not without grounds: a few decades earlier, the publication in 1544 of a Lutheran catechism in Slavonic characters in Sibiu, Transylvania, specifically targeted the Orthodox Romanians, and in 1559 a Romanian Lutheran catechism was forcibly imposed on the Romanian churches of the district of Braşov. ${ }^{27}$ As observed by Maria Crăciun, attempts at

${ }^{24}$ Pamiatniki polemicheskoi literatury $\mathrm{v}$ Zapadnoi Rusi (Russkaia istoricheskaia biblioteka 19), 3 (St Petersburg, 1903), cols 213-14.

${ }^{25}$ See Orest Levitskii, "Predislovie”, pp. 48-49; Dovbyshchenko, Volyns'ka shliakhta, pp. 465-66.

${ }^{26}$ Levitskii, "Sotsinianstvo v Pol'she i Iugo-Zapadnoi Rusi”, p. 56; Ohienko, “Reformatsiia v Pol'shchi”, p. 177; Dmitriev, Pravoslavie i reformatsiia, p. 108;

O.P. Kryzhanivs'kyi and S.M. Plokhy, Istoriia tserkvy ta relihiinoï dumky v Ukrä̈ni (Kiev, 1994), 3, p. 10.

${ }^{27}$ Christine Peters, "Mural Paintings, Ethnicity and Religious Identity in Transylvania: the Context for Reformation", The Reformation in Eastern and Central Europe, ed. Maag, p. 97. 
the dissemination of Protestant translations of the Scriptures and other works in Romanian printed in Germany among the Orthodox population of Moldavia in 15621563, was an indication of the European Evangelical Reformers' "interest in fostering the Reformation in Orthodox settings" ${ }^{28}$ By contrast, in the Polish-Lithianian Commonwealth polemical anti-Protestant treatises by local Orthodox activists continued to circulate in manuscript form up until the end of the $16^{\text {th }}$ century, which limited and slowed down dissemination. ${ }^{29}$ Even when the printing press finally made its appearance among the Orthodox of Poland-Lithuania ca. 1570, its output remained confined to liturgical texts for at least another decade. At the time when both Protestants and Catholics fully availed themselves of the opportunities for self-promotion offered by print, the Orthodox seemed to let them pass.

The arrival of the Jesuits signalled the beginning of both Catholic reform and the Counter-Reformation in Poland-Lithuania. From 1565 onward Jesuit colleges began to be established throughout the country. By the end of the $16^{\text {th }}$ century the order ran thirty-six schools in the Commonwealth's important urban centres. ${ }^{30}$ As many as twenty-three Jesuit schools operated in Ruthenia alone. ${ }^{31}$ Compared with the basic nature of

${ }^{28}$ Crăciun, "Protestantism and Orthodoxy in 16"-Century Moldavia", p. 133; Dmitriev, "Western Christianity and Eastern Orthodoxy", pp. 333-334.

${ }^{29}$ See, for example, Arkhiv IuZR, I, 8, pp. 3-44; Pamiatniki polemicheskoi literatury, 3, cols 47-100.

${ }^{30}$ R.A. Houston, Literacy in Early Modern Europe: Culture and Education, 1500-1800 (London, 1988), p. 36.

${ }^{31}$ Demianovich, “Iezuity v Zapadnoi Rossii (v 1569-1772 godakh)”, Zhurnal Ministerstva narodnogo prosveshcheniia, 8 (1871), p. 207. For more statistics on Jesuit 
contemporary Orthodox schools, the growing prestige of Catholic education ensured an influx of young Orthodox noblemen to Jesuit colleges and before long--Catholic conversions. With the confessional balance in the region shifting in favour of Catholicism, some newcomers to Protestantism, too, began to have second thoughts about their choice of religion.

In spite of smouldering intolerance on both sides, the Catholic and the Orthodox Churches held a common legacy of shared tradition expressed, among other things, in the veneration of the Virgin and saints, prayers for the dead, the seven sacraments, the worship of images, and the cycle of fasts. With Calvinism and Unitarianism making big strides throughout the Commonwealth, including Ruthenian palatinates in the east, it became increasingly clear that in the absence of hard and fast doctrinal certainties, any choices made with regard to Orthodox church life and practice were likely to bring them close to either side in the Catholic-Protestant debates. Accustomed to living cheek by jowl with Roman Catholics and willing to maintain the status quo, the Orthodox clerical hierarchy seemed to prefer the devil they knew to a "heretical" companion they disliked.

Compared with Catholicism, the structure of ecclesiastical power within the Eastern Church has always been marked by a notable absence of centralized authority. For the Orthodox believers of Poland-Lithuania, up until the $17^{\text {th }}$ century the church's supreme power was epitomized by the combined authority of the four Eastern patriarchs, all of whose seats (Constantinople, Alexandria, Antioch and Jerusalem) had been located

schools in the Kingdom of Poland see Piotr Stolarski, Friars on the Frontier: Catholic Renewal and the Dominican Order in Southeastern Poland, 1594-1648 (Farnham, 2010), pp. $64-65$. 
in Ottoman territory by the early $16^{\text {th }}$ century. Although the presence of patriarchal representatives from the Orient in Ruthenia was a constant feature of Orthodox religious life, the short period between 1585 and 1589 witnessed several unprecedented visits from the patriarchs themselves. Both the timing of their visits and the actions the patriarchs undertook in Poland-Lithuania suggest that they were driven by pastoral concerns and the desire not to let things run their course unobserved in this important theatre of "triangular [confessional] struggle" between the Orthodox Church, Protestantism and Rome. ${ }^{32}$

However well meaning, the impact of patriarchal visits on church affairs in the Commonwealth was destabilizing: unaware of the subtleties of the political situation on the ground and not conversant with local languages, they interfered with matters whose complexity eluded them, offended sensibilities and were prone to making hasty judgements. In addition, the patriarchs and their representatives were viewed with suspicion by the Commonwealth authorities, who questioned their legitimacy and intentions on a different level. Several visiting Greek divines, including the patriarchs themselves, were accused of spying and sabotage on behalf of the sultan. ${ }^{33}$ But in the long-term perspective, by upsetting the balance of power between the laity and the episcopate, patriarchal interference provided the necessary stimulus for future reforming initiatives in the Ruthenian Church. Moreover, the creation of the fifth patriarchal see in Moscow by Patriarch Jeremiah II in 1589 added another powerful element to the complex structure of ecclesiastical authority in the region. It set off the process whereby the

\footnotetext{
${ }^{32}$ See Jobert, De Luther à Mohila, p. 322.

${ }^{33}$ Kryzhanivs'kyi and Plokhy, Istoriia tserkvy ta relihiinö̈ dumky v Ukraïni, 3, p. 57; Frick, Meletij Smotryc'kyj, pp. 76-77.
} 
metropolitan see of Kiev, the centre of ecclesiastical power in Ruthenia for seven hundred years, would more or less unwillingly switch its canonical allegiance from Constantinople to Moscow almost a century later.

In the crown-lands of Poland-Lithuania royal and noble right of investiture to ecclesiastical titles and properties was all too often combined with pecuniary considerations on the part of the patrons. This meant that church offices often went to the best connected candidate or to the highest bidder, with little or no regard for their qualifications or marital status (in the Orthodox Church twice-married individuals were deemed canonically unsuitable for church office). Some even refused to give up secular status and part with their wives and children. ${ }^{34}$ In addition, patron-appointed lay caretakers of vacant dioceses and other ecclesiastical benefices openly regarded them as a source of revenue, especially where a different confessional allegiance made them indifferent or unsympathetic to the needs of the Eastern Church. The tradition of secular patronage pervaded both Catholic and Orthodox ecclesiastical structures from top to bottom. This had certain practical advantages, but the political weakness and devolved structure of authority in the Orthodox Church made it precariously dependent on the whims of the lords. ${ }^{35}$ After 1569 , the Ruthenian Orthodox nobility's exclusive right to occupy episcopal sees that belonged to the Eastern Church was enshrined in the

\footnotetext{
${ }^{34}$ Levitskii, "Predislovie", p. 58; Boris Floria, "Krizis organizatsionnykh struktur pravoslavnoi tserkvi v XVI v.”, Brestskaia uniia 1596 g. i obshchestvenno-politicheskaia bor'ba na Ukraine i v Belorussii v kontse XVI-nachale XVII v., ed. Boris Floria, 1, (Moscow, 1996), pp. 35-36.

${ }^{35}$ See Dovbyshchenko, Volyns'ka shliakhta, pp. 175-179.
} 
Commonwealth constitution. ${ }^{36}$ Boasting an influential and wealthy family background and presiding prince-like over vast dioceses, the bishops of the Eastern Church displayed little interest in maintaining priestly standards, clerical discipline and monastic regulations.

At the same time, in the Byzantine tradition the laity had been long accustomed to having a moderate say in ecclesiastical life. The Orthodox revival in Poland-Lithuania was set in motion by the burghers of Lviv, a city in the western periphery of the Ruthenian lands. A confraternity of laymen, which organized itself around the Church of the Assumption of Our Lady ca. 1585, established a printing press, and founded a school of "Greek and Slavonic letters". In 1586 they secured a charter from the visiting Patriarch Joachim of Antioch, which freed them from local episcopal jurisdiction and placed the confraternity under the authority of the Metropolitan of Kiev. Emboldened by patriarchal support, the Orthodox burghers of Lviv began to fashion themselves as guardians of the purity of the faith. ${ }^{37}$ The confreres took their religious liberties too far when they began to harass the bishop of Lviv for alleged breaches of acceptable pastoral conduct. In a letter to the Patriarch of Constantinople, they painted the Orthodox episcopate in an altogether negative light, directly attributing the current crisis in the church to their nefarious influence. In particular, the bishops were accused of being loath to correct the errors of

\footnotetext{
${ }^{36}$ P. Zhukovich, "Brestskii sobor 1591 goda (po novootkrytoi gramote, soderzhashchei deianiia ego)", Izvestiia Otdeleniia russkogo iazyka i slovesnosti Imperatorskoi akademii nauk, 12 (1907), pp. 49-50, n. 3.

${ }^{37}$ Levitskii, "Predislovie", pp. 78-79.
} 
inept priests for fear of revealing their own inadequacies. ${ }^{38}$ That the episcopate did not take lay meddling meekly is shown by the angry retort of the Bishop of Lviv Gedeon Balaban (1569-1607) to the burghers of a small provincial town in his diocese who had requested that he instruct them in the faith and scripture as the Apostle Paul had done: "[You say] I should teach you, peasant, but you have just emerged from the manure heap-what business ... do you have with scripture?"39 Seeing patriarchal interference as the root of the troubles caused him by disobedient laymen, the aggrieved Bishop Balaban is even reported to have taken the unprecedented step of addressing the Catholic Archbishop of Lviv Jan Dymitr Solikowski (1583-1603) with a tearful plea to help him and his fellow Orthodox bishops to rid themselves of the tyranny of the Eastern Patriarchs. ${ }^{40}$

More Ruthenian urban centres followed suit by organizing lay Orthodox confraternities on the template developed in Lviv, opening schools and printing presses and similarly trying their hand at challenging episcopal jurisdiction. On his way to Moscow, on 5 June 1588 the Patriarch of Constantinople Jeremiah II approved the statute of the newly established confraternity in Vilnius. The document pronounced anathema on any metropolitan or bishop who obstructed the confraternity's work, made slanderous pronouncements against its members or brought discord in their midst. ${ }^{41}$ Many Orthodox

\footnotetext{
${ }^{38}$ Boris Floria, "Episkopy, pravoslavnaia znat' i bratstva. Vopros o reforme tserkvi v poslednie desiatiletiia XVI v.”, Brestskaia uniia 1596 g., ed. Floria, 1, p. 99.

${ }^{39}$ Cited in Floria, "Episkopy, pravoslavnaia znat' i bratstva”, p. 99.

${ }^{40}$ Arkhiv IuZR, I, 10 (Kiev, 1904), p. 497.

${ }^{41}$ Floria, “Episkopy, pravoslavnaia znat' i bratstva”, p. 101.
} 
nobles supported the townspeople against the bishops, contributing to a perceptible divide between the clerical hierarchy and the laity. This marked anticlericalism of the Orthodox laity may have originated from within the church itself, although it is clear that Protestant examples also played a part. ${ }^{42}$

One consequence of Patriarch Jeremiah's two sojourns in Ruthenia was the revival in 1589 of local church synods that had not been convened in the preceding thirty years. ${ }^{43}$ Bringing together bishops, abbots and other ecclesiastical officials, and lay representatives, they were traditionally viewed as the mainstay of collective authority within the Orthodox Church understood as the body of the faithful. At this juncture the Orthodox laity's heightened activity, combined with the bishops' cautious readiness to cooperate, meant that a consensus-based church reform was still a possibility. The next such gathering of Orthodox dignitaries and secular activists in the Lithuanian city of Brest in 1590 was a pivotal event that paved the way for a series of church synods that took place there between 1591 and 1596. They addressed educational and cultural

\footnotetext{
${ }^{42}$ Iaroslav Isaievych in his authoritative book on Ruthenian lay confraternities (first published in 1966) argued that their seemingly Protestant tendencies were the result of some "local conditions": Iaroslav Isaievych, Voluntary Brotherhood: Confraternities of Laymen in Early Modern Ukraine (Edmonton, Toronto, 2006), p. 101. (See my review of the revised English translation of Isaievych's work in the English Historical Review, 73 (2008), 1546-1548). Cf. Dmitriev, "Les confréries de Ruthénie dans la deuxième moitié du XVI siècle". Other scholars link the origins and activity of confraternities to the Protestant and Catholic reforms more directly: Levitskii, "Predislovie", p. 72; Kryzhanivs'kyi and Plokhy, Istoriia tserkvy ta relihiinoï dumky v Ukraïni, 3, pp. 16-17. ${ }^{43}$ Zhukovich, "Brestskii sobor 1591 goda", p. 45.
} 
concerns close to the heart of lay confraternities, attempted to tackle the problems arising from the excesses of royal and noble patronage, and moved to discipline the bishops. However, more than anything else, the Orthodox Church synods of 1591-1596 put in sharp relief the relentless tug-of-war between the laity and the episcopate. By the end of the period this would lead to an open schism.

The episcopate tried to seize the initiative at the synod of 1591: while praising the educational and publishing activities of confraternities, they put themselves in charge of the censorship of religious publications to ensure that lay associations "published nothing without the approval and blessing of their shepherds and printed no new books based on ... fanciful conceits". The bishops also promised to help finance publishing enterprises and establish schools in their dioceses. ${ }^{44}$ A series of proposals was put forward, aimed at excluding unworthy candidates from consecration as secular priests. ${ }^{45}$ Finally, the synod undertook to streamline the procedure of episcopal appointments. ${ }^{46}$ It is also clear that by agreeing to do so the bishops hoped to reduce lay interference and to strengthen their own hand.

In the run-up to the 1594 synod, a group of Orthodox senators and noble representatives produced a blueprint of reforms proposed by the estates. This programme opened with a forceful statement of the centrality of confraternities to the process of

\footnotetext{
${ }^{44}$ Zhukovich, "Brestskii sobor 1591 goda", p. 68. I am citing from the full text of the proceedings of the 1591 Synod of Brest, appended to Zhukovich's article (pp.65-71). 
restoring the Orthodox Church to its pristine ancient purity. ${ }^{47}$ It also contained a demand for the bishops' activity to be strictly regulated in ways determined by the laity. Heads of dioceses were required to give back the church properties they had unlawfully seized and turned into private possessions, and to give up a certain share of their income to maintain schools and printing presses. The bishops had to stop "electing themselves based on promises instead of merit", and the participation of secular delegates in episcopal elections was to become mandatory. ${ }^{48}$ Finally, to ensure the canonicity of church life, the nobles' programme of reforms contained renewed demands that church synods take place on an annual basis and insisted on the permanent presence of patriarchal representatives in Poland-Lithuania. ${ }^{49}$

The proposals were duly considered by the synod, although in the light of their barely disguised militancy towards the episcopate, there is little surprise that only a few of them were accepted. The hierarchy of the Orthodox Church agreed to support the new procedure of episcopal elections at provincial diets, but objected to the proposed limitations on episcopal authority and the demand to free the publishing activity of confraternities from the bishops' controls. ${ }^{50}$ Despite the synod's seemingly reasoned response to the nobility's programme of reforms, subsequent events demonstrate with great clarity that the episcopate was growing both weary, and wary, of lay opposition. For the bishops, a church in which the laity held the upper hand, chose their priests and

${ }^{47}$ Arkhiv IuZR, I, 10, p. 497.

${ }^{48}$ Arkhiv IuZR, I, 10, p. 498-99.

${ }^{49}$ Arkhiv IuZR, I, 10, p. 498.

${ }^{50}$ AZR, 4 (St Petersburg, 1848), pp. 68-69. 
scrutinized their behaviour and morals came uncomfortably close to the erroneous conceit of the "Luthers" that any true believer could be a priest without consecration or episcopal sanction.

While both sides in the debates now seemed to agree on the need for reforms, the bishops perceived them as a set of top-down measures largely aimed at imposing order and discipline among the priesthood and the faithful. Thus proposed changes with regard to episcopal authority involved curtailing the power of lay patrons over church benefices at all levels. On the whole, members of the Orthodox hierarchy predicated their idea of reform on strengthening ecclesiastical structures and curtailing lay initiative. At the same time, the laity's view of church reform was becoming increasingly radical, as both Orthodox nobility and confraternities were beginning to sound as if continued excesses of episcopal power were forcing them to think of ways of effecting a bottom-up church reform to isolate the bishops. For all their struggles against episcopal authority and attempts to secure a hold over education, publishing and the correct interpretation of scripture, the Orthodox laity harboured no desire to become Protestant. But similar problems are susceptible to similar solutions without deliberate imitation. The everyday reality of life in a multi-confessional state like Poland-Lithuania gave the opponents of broad lay participation in religious affairs enough experience of where this path might lead if things were allowed to run their course. They feared that the outcome would resemble just another quasi-Protestant sect. As an associate of Gedeon Balaban wrote in 1590:

They [the confraternities] are beginning [to act] in the same way as Martin Luther, who had begun by criticizing the blessing of water, and later great heresies arose. 
For even they [the confraternities] have launched an attack on other sacraments, saying that confession and communion are not needed, except in cases of severe illness or on the verge of death... They already look with disfavour upon baptism, declaring that people should be baptized not in childhood, but at thirty years of age. $^{51}$

The author's peculiar views of Luther's protest and evident rhetorical flourishes should not detract from the sense of urgency in the bishops' belief that the spread of Protestantism had to be stemmed. Both sides in the debate credited themselves with making strenuous efforts to "arrange [Orthodox] religious affairs in accordance with the ancient good hallowed order". ${ }^{52}$ But a dual association between lay initiative in church reforms and Protestantism, on the one hand, and episcopal opposition to it--with Catholicism, on the other, had already been established by 1590. Protestant influence helped the laity formulate their challenge to the status quo, while the bishops looked to Catholic models to buttress their particular view of the Church and their own authority. Such distribution of confessional preferences among the laity and the episcopate does not seem to have been unique to the Orthodox of Poland-Lithuania, however, as it is known that a succession of reform-minded Orthodox patriarchs of Serbia from Jovan Kantul (1592-1614) to Maksim (1655-1674) maintained contacts with Rome through Catholic missionaries. ${ }^{53}$

\footnotetext{
${ }^{51}$ Cited in Isaievych, Voluntary Brotherhood, p. 101.

${ }^{52} A Z R, 4$, p. 34.

${ }^{53}$ Dmitriev, "Western Christianity and Eastern Orthodoxy", pp. 325-326.
} 
Following the first synod at Brest in 1590, a group of Orthodox bishops met to discuss their position vis-à-vis patriarchal authority, the metropolitan, and the laity. There a possibility of forging a permanent alliance with the Roman Catholic Church was raised. An address to the Polish King Sigismund III was put together, which stated the readiness of the episcopate to seek understanding with the Pontifical See if the Polish-Lithuanian state would guarantee the Eastern Church the retention of its ancient privileges and established order. Such guarantees were certainly outside the king's limited constitutional prerogatives, but the appeal was merely a political move, expected to secure his support and intercession with Rome. In addition, the bishops may have been tentatively asking for Sigismund's backing in any future negotiations with the local Catholic hierarchy, which, as they knew only too well, would be reluctant to permit the Orthodox both to retain their separate rite and to increase their standing in the Commonwealth. ${ }^{54}$ The fact that the bishops addressed their petition to the king before approaching the Roman curia is an indication that the resolution of political issues within the Commonwealth was considered as a stepping stone in the subsequent talks about church union with the papacy.

After a period of hesitation, the laity's hostile stance at the 1594 synod finally propelled the episcopate into action. A meeting in Sokal approved a resolution to compile

${ }^{54}$ I am indebted to Professor Robert Frost for pointing out that, far from displaying surprising political naivety or committing an error of judgement in trying to secure support from the constitutionally emasculated monarch of the Commonwealth, the Orthodox bishops gambled on curbing potential opposition to their project by trying to present, in the true spirit of the Confessional Age, the union of churches as a corollary of political unity. 
a list of conditions for the union of churches. ${ }^{55}$ The idea of a regional union between the Orthodox Church in Ruthenia and the Roman See had been floated before, notably by the Jesuit polemicist Peter Skarga in his book On the unity of the Church of God under one shepherd, and of the Greek and Ruthenian apostasy from that unity. ${ }^{56}$ The ebullient mood of Skarga's work--he archly proclaimed that the Orthodox stood in need of civilizing as much as evangelizing--makes it easy to explain why both Orthodox secular leaders and the Orthodox believers at the grassroots level found such an idea unpalatable. ${ }^{57}$ In the preface to the second edition of his book in 1590, Skarga advised the reader that wealthy Ruthenians had bought out most of the initial print run and destroyed it out of spite. There is no question that a regional union was achievable in principle, but the simplicity of this solution was deceptive as it concealed a significant problem: clearly the weaker of the two sides entering the arrangement, the Orthodox Church would have to acknowledge Catholic supremacy. An alternative "universal" type of union with its system of geopolitical checks and balances (such as the approval from the Eastern patriarchs and the support of the Muscovite tsar) held out a better guarantee of security to the Eastern Church. The absence of a native Orthodox monarchy and state sponsorship in PolandLithuania, as well as the lack of educational facilities run by the Orthodox and thus free

${ }^{55}$ Akty, izdavaemye Komissieiu ... dlia razbora drevnikh aktov v Vil'ne, 19 (Vilnius, 1892), p. 366.

${ }^{56}$ O jedności Kościoła Bożego pod jednym pasterzem i o Greckiem i Ruskiem od tej jedności odstąpleniu (Cracow, 1577).

${ }^{57}$ Pamiatniki polemicheskoi literatury, 2, cols 482-88. 
from rival proselytizing made a regional union a hard act to sustain without jeopardizing the essential integrity of Eastern ritual and belief.

By the end of 1594 Hypatius Potii, the Bishop of Vladimir and Brest, and Cyril Terletskii, the Bishop of Lutsk and Ostrih, drew up a draft of thirty-two "articles" or demands of the episcopate, which were to provide the basis for the future union of churches. Only nine articles were directly addressed to the pope, while the resolution of the remaining twenty-three depended on the Polish-Lithuanian state. ${ }^{58}$ In dogmatic terms the contentious issue of the passage of the Holy Ghost (filioque) was to be resolved in line with the compromise reached at the Council of Florence, but the Orthodox rite was to be kept unchanged, and the institution of clerical marriage for secular priests preserved. External jurisdiction over the Eastern Church was to pass from the patriarch of Constantinople to the Roman pope. Like their Roman Catholic counterparts, all Orthodox bishops were to obtain the right to sit in the Senate; the quota of their representation was to equal that of the Catholic episcopate. No Greek clerics from the Ottoman territories, likely to incite confessional division, were to be allowed to cross the Commonwealth borders, and no patriarchal writs were to be effective within them. All monasteries, churches and lay confraternities of the Eastern rite were to be subjected to local bishops. The Orthodox clergy had to be given equal rights with Catholics (e. g. exemption from taxes), and the ecclesiastical jurisdiction was to supersede the powers of secular patrons. The properties taken away from the Eastern Church in the past were to be restored, and

\footnotetext{
${ }^{58}$ Boris Floria and Sergei Iakovenko, "Vnutrennii krizis v pravoslavnom obshchestve i proekty unii s Rimom 90-kh godov XVI veka", Brestskaia uniia 1596 g., ed. Floria, 1, p. 149.
} 
the institution of secular caretakers of ecclesiastical benefices abolished. The final version of the document was approved by the church synod held in Brest in June $1595 .{ }^{59}$

A polemical pamphlet published in 1595 and attributed to Potii provides a glimpse of the Orthodox episcopate's vision of their church's position vis-à-vis other Christian confessions in Poland-Lithuania. ${ }^{60}$ Apparently intended as a programmatic statement about the main differences between the Orthodox and the Roman Catholic churches and the ways to overcome them, the work was in fact an attack on Protestants and those in the Eastern Church sympathetic to the Evangelical beliefs. These Protestant sympathizers were described, characteristically, as "people of common, simple stock, artisans, who, having abandoned the tools of their trade (thick thread to make shoes, scissors and bradawl), arrogated themselves to a priestly order to manipulate God's scripture, nullify and twist it to make it serve their ludicrous and false inventions". ${ }^{61}$ The real message of the pamphlet explains the author's curious choice of "differences" that allegedly separated Orthodox and Catholic, but in fact represented a set of shared points they held against the common enemy, Protestantism. Thus the issues treated in the pamphlet are those of the filioque, existence of purgatory, papal primacy, the Gregorian calendar reform and the representation of the Antichrist. The push for reform was explained in the following way: neglected by their pastors (i. e. the Eastern patriarchs),

${ }^{59}$ Athanasius G. Welykyj, ed., Documenta Unionis Berestensis eiusque auctorum (15901600), Analecta OSBM, Series II, Sectio III: Documenta Romana Ecclesiae Unitae in terris Ucrainae et Bjelarusjae (Rome, 1970), pp. 61-75.

${ }^{60} \mathrm{~A}$ remark in the text indicates that the pamphlet was authored by a Ruthenian Orthodox bishop, see Pamiatniki polemicheskoi literatury, 2, col. 115.

${ }^{61}$ Pamiatniki polemicheskoi literatury, 2, cols 118-19. 
some Orthodox believers strayed from the straight and narrow path and became attached to Protestant sectarians: "Luther, Calvin ... [and] the accursed Arius". ${ }^{2}$ Others made a more intelligent choice and went over to the Catholics, attracted by good causes and a better order. The proposed union of churches would bring about the ancient unity, which had existed under the Fathers of the Church and which the bishops were now striving to re-establish. ${ }^{63}$ The centrepiece of the pamphlet's argument is the section dedicated to the claims some Orthodox picked up from Protestants, which identified the Roman pope as the Antichrist. ${ }^{64}$ Focusing on such familiar concerns of the Orthodox as the validity of the seven sacraments and the church tradition, iconoclasm and the veneration of saints, the author attempted to prove, if only by sleight of hand, that Protestants were in fact the true servants of the Antichrist. ${ }^{65}$ The work betrays considerable familiarity with Evangelical beliefs, including brief references to predestination and salvation by faith alone, habitually ignored by Orthodox polemicists. ${ }^{66}$ This substantiates the hypothesis of Potii's authorship, since he had been a convert to Calvinism before reconciling himself with the Orthodox Church at the age of thirty-three. ${ }^{67}$

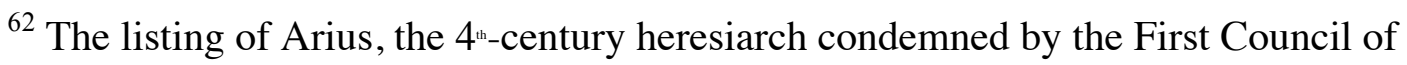
Nicaea (325), alongside Luther and Calvin is noteworthy.

${ }^{63}$ Pamiatniki polemicheskoi literatury, 2, col. 114.

${ }^{64}$ See Bortnik, "Problem tolerancji w prawosławnej myśli teologicznej”, p. 168.

${ }^{65}$ Pamiatniki polemicheskoi literatury, 2, cols 162-65.

${ }^{66}$ Pamiatniki polemicheskoi literatury, 2, cols 163, 165.

${ }^{67}$ See Borys Gudziak, Kryza i reforma: Kyïvs'ka mytropoliia, Tsarhorods'kyi patriarkhat i heneza Beresteis 'koï unï (Lviv, 2000), p. 279. 
The bishops' project expressed in the "Thirty-Two Articles" was an impressively ambitious piece of statesmanship. If fulfilled in all or most of its key points, it would have placed the Ruthenian branch of the church, newly unified under papal authority, in a position of regional autonomy, unique in the post-Reformation Catholic world. The bishops were not mistaken about the enthusiastic reception from the Polish crown for their unionizing initiative, but they seriously overestimated the ability of the king to support it in practice. By his decrees of 30 July and 2 August 1595 Sigismund III agreed to relinquish some of the royal rights of patronage by accepting the proposed procedure of episcopal elections and agreeing to subject all churches, confraternities, schools and printing presses operating in the crown lands to the bishops' jurisdiction. But he was powerless to limit noble rights of patronage with regard to Orthodox benefices ${ }^{68}$ Having initially declared his readiness to grant the clergy of the Eastern rite the same privileges as those enjoyed by their Catholic counterparts, Sigismund fell back on a more cautious declaration of intent to facilitate the later dialogue on the subject between Catholic and Orthodox. ${ }^{69}$ The question of the Senate seats for the bishops of the Eastern rite lay outside royal jurisdiction. ${ }^{70}$

To receive parliamentary approval, the bishops' initiative required noble support. Yet their overtures aimed at securing cooperation from the Orthodox princely aristocracy, represented by Constantine Ostrozskii, had the opposite effect. In June 1595 the prince had a pamphlet published in Ostrih, in which he urged the Orthodox population of

${ }^{68} A Z R, 4$, pp. 111-112.

${ }^{69} A Z R, 4$, pp. 110, 112.

${ }^{70} A Z R, 4$, p. 111. 
Poland-Lithuania to reject the union project. ${ }^{71}$ Printed copies of the tract were widely disseminated throughout the Commonwealth. Two months later he sent a representative to the general synod of Protestant confessions in Toruń, calling on them to join the Eastern Church in resisting Sigismund III's attack on noble liberties and even to consider levying troops for this purpose. It was noted in the synod proceedings that Ostrozskii's envoy also spoke for the Orthodox senators and nobility of the four major eastern palatinates of Poland where the Orthodox were present in force: Kiev, Volhynia, Podolia and Red Ruthenia. ${ }^{72}$ This broad secular support undoubtedly explains Ostrozskii's extraordinary defiance. The king's actions were regarded as an infringement of the noble right to the free profession of religion, safeguarded under the 1573 Confederation of Warsaw. Unsettled by the strength of opposition to the union project, two of the seven Orthodox bishops: Gedeon Balaban of Lviv and Michael Kopystenskii of Przemyśl and Sambir (1591-1609), broke ranks and declared against it. ${ }^{73}$ In the face of growing antagonism, the remaining pro-union bishops abandoned the initial idea that securing proper royal and papal guarantees of special rights and privileges for the Eastern Church should precede the union agreement. Potii and Terletskii, the authors of the original

\footnotetext{
${ }^{71}$ AZR, 4, pp. 99-104.

${ }^{72}$ Kazimierz Chodynicki, Kościoł prawosławny a Rzeczpospolita Polska: Zarys historyczny, 1370-1632 (Warsaw, 1934), pp. 305-307.

${ }^{73}$ Welykyj, ed., Documenta Unionis Berestensis, pp. 59-60; Arkhiv IuZR, I, 1 (Kiev, 1859), pp. 453-456; also see Boris Floria and Sergei Iakovenko, "Raskol zapadnorusskogo pravoslavnogo obshchestva na dva lageria, provozglashenie unii tserkvei v Rime. Brestskie sobory 1596 g. i zakreplenie raskola”, Brestskaia uniia 1596 g., ed. Floria, 1, p. 179.
} 
"Thirty-Two Articles", left for Rome for the final stage of the negotiations. The urgency of their purpose is illustrated by the fact that to release funds for the trip, Terletskii requested the king's permission to use the estates that belonged to his see and were reserved for the bishop's upkeep as security against a loan. ${ }^{74}$

Accustomed to the relative laxity of patriarchal controls, the Orthodox episcopate was clearly unaware of the magnitude of concessions they were seeking from the papacy. With the Catholic Church strengthened and reassured by its post-Tridentine renewal, and buoyed by the heroic progress of its overseas missions in the Indies and by recent successes of the Counter-Reformation in Europe, its old ecclesiological certainties seemed ever more fixed. Roman emphasis on the importance of the papacy as the visible representation of the invisible Christ favoured hierarchy, centralization, discipline and universality. To enter into negotiations on the union of churches with a group of bishops merely representing a regional branch of the "schismatic" Orthodox confession would have been tantamount to imbuing the Ruthenian archbishopric with the status of a separate church. Far from trying to negotiate conditions, the Ruthenians, like their fellow Orthodox believers elsewhere in Europe, were expected to renounce their dogmatic errors and obtain the hope of salvation in return. The preservation of the Orthodox rite, which the Ruthenian party upheld as the principal condition of their union project, was acceptable to Rome not as a means to reach a compromise solution, but only because it was non-essential from the Roman Catholic doctrinal viewpoint. ${ }^{75}$

\footnotetext{
${ }^{74}$ Arkhiv IuZR, I, 1, pp. 458-60; the lease agreement ibid., pp. 460-67.

${ }^{75}$ Peri, “Beresteis'ka uniia u ryms'komu bachenni”, pp. 15-16.
} 
This explains why during the four months of Potii and Terletskii's sojourn in Rome until March 1596 no discussion took place between Roman theologians and the two Orthodox bishops. ${ }^{76}$ At that time the "Thirty-Two Articles" were examined by the bodies in the curia such as the Congregation of the Inquisition and the Greek Congregation, but the document was scrutinized for its compliance with Catholic dogma, not as an instrument in diplomatic negotiations. At a solemn ceremony on 23 December 1596 Potii and Terletskii read out the confession of faith prepared by the curia officials, which complied with Catholic dogma both in spirit and in letter and proclaimed their fidelity not only to the decisions of the Council of Florence, but also to the Tridentine decrees. ${ }^{77}$ The sheepish acquiescence of the two Ruthenian envoys in the dictates of the curia has a dual explanation. On the one hand, in the face of overwhelming hostility from the Orthodox, Potii and Terletskii's homecoming with the act of union under their belt would earn them support and protection from the crown. The bishops might also have hoped that diplomatic assistance from Rome would improve their chances of securing further concessions from the state--and placate the laity. ${ }^{78}$ On the other hand, they clearly believed that they had secured the sine qua non condition of the union of churches as at least some of the Orthodox would see it: the continued integrity of the Eastern rite. ${ }^{79}$

\footnotetext{
${ }^{76}$ Floria and Iakovenko, "Raskol zapadnorusskogo pravoslavnogo obshchestva", p. 185.

${ }^{77}$ Welykyj, ed., Documenta Unionis Berestensis, pp. 211-216.

${ }^{78}$ Floria and Iakovenko, "Raskol zapadnorusskogo pravoslavnogo obshchestva”, p. 187.

${ }^{79}$ Welykyj, ed., Documenta Unionis Berestensis, pp. 217-26.
} 
A church synod convened in Brest in October 1596 publicly to proclaim the act of union condemned its opponents and declared them deposed from office. ${ }^{80}$ This famous "synod of Brest" was attended by the Metropolitan Michael Ragoza, the four pro-union bishops and the clergy of their dioceses who accepted the union, several high-ranking officials of the Polish-Lithuanian state and a large number of Catholic clergy. An alternative "synod of Brest" that brought together supporters of the "disunited" Orthodox Church simultaneously took place in the same city, attended by two representatives of the Eastern patriarchs, Orthodox clergy of various ranks, including the two bishops who rejected the union, heads of monasteries and a number of noble deputies, predominantly from the Kingdom of Poland, led by Constantine Ostrozskii. ${ }^{81}$ This Orthodox synod declared the unionizing bishops impostors and called on the Orthodox faithful to reject the union. ${ }^{82}$

As a result of the top-down reform led by the episcopate, the Eastern confession in Ruthenia split into two antagonistic camps: the "Greek Catholic" and the "Greek Orthodox". The Greek Catholics secured official status as the Church of the Eastern Rite in the Commonwealth, while the Orthodox lost legal standing with the Polish-Lithuanian state and with it the right to a separate church administration, as well as any entitlement to benefices and ecclesiastical properties. Aimed at unifying and strengthening the church, the first phase of the bishops' reform caused a new schism.

${ }^{80} A Z R, 4$, pp. $139-41,148-49$.

${ }^{81}$ Kryzhanivs'kyi and Plokhy, Istoriia tserkvy ta relihiinoï dumky v Ukraïni, 3, p. 48. ${ }^{82} A Z R, 4$, pp. 141-42. 
One of the most significant consequences of the loss of legal standing by the Orthodox Church was that it could no longer have a proper hierarchy of bishops: under the law of patronage the withdrawal of royal approbation meant that no episcopal appointments could legitimately take place. Five of the seven episcopal sees were filled with Greek Catholics. Following the death in 1607 of Gedeon Balaban, the Lviv Confraternity managed to install their own candidate, Eustaphius Tisarovskii, on the episcopal throne and to have him consecrated by the Moldavian Metropolitan of Suçeava. The demise of Michael Kopystenskii, the Orthodox bishop of Przemyśl, in 1609 left Tisarovskii the only "disunited" holder of an episcopal see in the entire Commonwealth. ${ }^{83}$ Bereft of a duly ordained and consecrated hierarchy, the church was facing an uncertain future. With time the disunited Ruthenians managed to wangle a few small, but meaningful concessions from the crown. Thus in exchange for support from Orthodox deputies to the 1603 Diet for a levy of taxes in aid of the king's war in Livonia, Sigismund agreed that the archimandrites (abbots) of the Kievan Caves Monastery, the oldest and grandest monastery in the East Slavic lands, would henceforth be chosen from Orthodox candidates. In the course of the rebellion of Sandomierz, a segment of the nobility representing all the main confessions including Catholics, protested against royal abuses of power. ${ }^{84}$ It resulted in a brief military alliance between the Orthodox and the Protestants, following which the Diets of 1607 and 1609 renewed the right for the

\footnotetext{
83 "The united" (Polish and Ruthenian unity) and "the disunited" (dizunity) were the terms adopted in $16^{\mathrm{t} \text { - }}$ and $17^{\mathrm{t} \text { - }}$-century usage to describe respectively the Greek Catholic and the Greek Orthodox Churches.

${ }^{84}$ Kamins'kyi, Istoriia Rechi Pospolytoï, pp. 93-94.
} 
Orthodox to conduct religious services and for private donors to give estates as a gift to Orthodox monasteries and churches. This in effect legitimized the existence of two churches of the Eastern rite in the Commonwealth, although their position vis-à-vis the state was not the same. ${ }^{85}$

It was not before 1620 that a new, if still very much illegitimate, Orthodox hierarchy with Job Boretskii at its head as the Metropolitan of Kiev (1620-1631) was consecrated by a reluctant Patriarch Theophanes of Jerusalem (1608-1644). He was returning from Moscow, where he had gone to appeal for alms. Most of the newly appointed bishops were heads of Orthodox monasteries in Ruthenia. ${ }^{86}$ Unfortunately for all concerned, the timing of the consecration was extremely awkward, as it took place within a fortnight of the disastrous defeat of the Polish army by the Ottoman forces at the Battle of Cecora in Moldavia ${ }^{87}$ Predictably, the state interpreted Theophanes's role as an act of sabotage by an Ottoman subject, and warrants were issued for the arrest of the newly consecrated Orthodox bishops on charges of treason. ${ }^{88}$ As a result most of them were unable to reside in their dioceses and had to stay permanently in Kiev under the protection of the Cossacks for fear of persecution. Theophanes's actions created a second

\footnotetext{
${ }^{85}$ Kryzhanivs'kyi and Plokhy, Istoriia tserkvy ta relihiinoï dumky v Ukraïni, 3, p. 57; also see Plokhy, Cossacks and Religion in Early Modern Ukraine, p. 87.

${ }^{86}$ For the distribution of the episcopal sees see Teresa Chynczewska-Hennel, "The Political, Social, and National Thought of the Ukrainian Higher Clergy, 1569-1700”, HUS, 24 (2002-2003), p. 109.

${ }^{87}$ Frick, Meletij Smotryc'kyj, p. 82.

${ }^{88}$ Frick, Meletij Smotryc'kyj, pp. 79-80.
} 
set of bishops who claimed possession, at least in theory, of the dioceses of the Eastern Church from their Greek Catholic rivals.

The problems and contradictions tearing at the body of the Eastern Church in the Polish-Lithuanian Commonwealth found expression in the life and career of Meletius Smotritskii (ca. 1577-1633), a member of the clandestine Orthodox hierarchy consecrated in 1620. After an abortive course of study at the Jesuit Vilnius Academy and subsequent study in Germany, he wrote one of the most explosive works of post-1596 anti-Catholic polemic, Threnos or lament ... of the Eastern Church ${ }^{89}$ Apart from listing numerous examples of religious oppression against the Orthodox Church, the treatise revealed the deplorable state of that church as seen from within: the avarice of bishops, the lack of education among the clergy, the falling away of the nobility, and the despair of the ordinary flock. It argued that the problems of the Orthodox Church did not lie in its inherently faulty nature, but rather in the absence of those eager and able to defend it. ${ }^{90}$ The book was reportedly read aloud at church services and meetings of lay confraternities, and some Orthodox devotees even ordered that they be buried with a copy in their coffins. In 1620 Smotritskii became the Orthodox Bishop of Polatsk, but he was soon forced to leave the Commonwealth as a result of being implicated in the gruesome murder of his rival, the legitimately appointed Greek Catholic bishop of Polatsk Josaphat Kuntsevich (1618-1623). On his subsequent travels in the Orient Smotritskii was apparently horrified by the popularity of Calvinist doctrine among the Greek divines. In

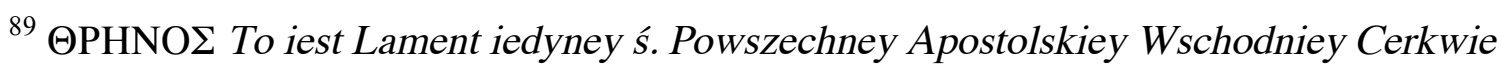
(Vilnius, 1610). On Meletius's education see Frick, Meletij Smotryc'kyj, p. 31. ${ }^{90}$ Mykhailo Hrushevs'kyi, Istoriia Ukraïny-Rusi, 6 (New York, 1955), pp. 594-598. 
Constantinople he was presented by the then Patriarch Cyril Lukaris (1620-1638) with his draft catechism of the Orthodox faith. ${ }^{91}$ Originally written in Latin and first published in Geneva in 1629, Lukaris's confession would be roundly condemned for its Calvinist character and subsequently formally rejected by six general synods of the Orthodox Church between 1638 and $1672 .{ }^{92}$

Smotritskii secretly became a Greek Catholic upon his return to the Commonwealth, armed with a patriarchal letter that brought all lay confraternities back to episcopal jurisdiction. He then began a series of private talks with the members of Orthodox Church hierarchy, calling to repudiate the authority of the Eastern patriarchs and join forces with Catholicism. Disowned by his ostensible allies after his conversion had become public amid much rumour and scandal, in his later writings this embittered former champion of Orthodoxy tried to persuade the papacy and secular powers in Poland-Lithuania forcibly to compel his former co-religionists to accept the union of churches. ${ }^{93}$ Extreme and paradoxical as it is, Smotritskii's example is a perfect illustration of the dynamics of situational responses to the position of the Orthodox Church vis-à-vis Catholicism and Protestantism. Smotritskii the commoner and lay religious activist was both the advocate and the toast of confraternities, a vehement critic of the episcopate not averse to applying Protestant polemical techniques in his own

\footnotetext{
${ }^{91}$ Frick, Meletij Smotryc'kyj, p. 99.

${ }^{92}$ Paschalis M. Kitromilides, "Orthodoxy and the West: Reformation to Enlightenment", Eastern Christianity, ed. Michael Angold, The Cambridge history of Christianity 5 (Cambridge, Eng., 2006), p. 199.

${ }^{93}$ Frick, Meletij Smotryc'kyj, p. 227.
} 
work. ${ }^{94}$ But Smotritskii the bishop moved to curtail what he saw as excessive lay liberties by reinforcing episcopal controls over voluntary lay associations, and he came to see the blueprint of Tridentine reforms as the best solution for the problems of the Eastern Church.

One of Smotritskii's alleged Orthodox collaborators in his unsuccessful mission covertly to bring about a new union of churches in 1627-1628 was the then Archimandrite of the Kiev Caves Monastery Peter Mohyla. A proud scion of a staunchly Orthodox Moldavian princely family and church figure of considerable standing, frequently described by contemporaries and later historians alike as a crypto-Catholic, he was no friend of the Evangelicals. Peter's native Moldavia had witnessed a period of antiLutheran persecution under Prince (Hospodar) Alexandru Lăpuşneanu (1552-1561), in whose service his paternal grandfather John had excelled and whose sister he had married. John Mohyla could have been forced to take monastic vows in 1563 by Alexandru's successor, Prince Jacob Basilicos Heraclides, known as Despot (1562-1563), who had espoused the Radical Reformation in its Antitrinitarian form. ${ }^{95}$ Mohyla's commonplace book whose records date to the late 1620 s and early 1630 s contains nearly sixty stories of miracles performed by the relics of Orthodox saints and Orthodox icons. ${ }^{96}$ Many of these tales focused on Catholic or Protestant miscreants who had offended the ${ }^{94}$ See Frick, Meletij Smotryc 'kyj, p. 208.

${ }^{95}$ Crăciun, "Protestantism and Orthodoxy in 16"-Century Moldavia", pp. 128, 132; Arkadii Zhukovs'kyi, Petro Mohyla i pytannia iednosty tserkov (Kiev, 1997), p. 38; Matei Cazacu, 'Pierre Mohyla et la Roumanie: essai historique et bibliographique', HUS, 8 (1984), p. 197.

${ }^{96}$ Arkhiv IuZR, I, 7 (Kiev, 1887), pp. 49-132. 
sacred objects and swiftly received divine retribution. But Mohyla's attitude to different confessions is revealed by the specific linguistic tags he attached to their representatives. Roman Catholics were described neutrally as the people of "Latin" or "Polish" faith and only provoked God's wrath when they behaved like the iconoclast Protestants, by deriding or physically desecrating Orthodox relics. At the same time, the Catholic bishop of Kiev, who lectured his fellow-believers on the need to venerate Orthodox relics as they would their own saints, was shown in an altogether positive light. We even learn that his valuable riding horse was cured after his master prayed before the miracle-working icon of the Virgin in the main church of the Orthodox Caves Monastery $!{ }^{97}$ Mohyla reserved much harsher language for the Greek Catholics, whose faith was described as the "souldestroying apostasy", "gangrene" and "cancer" ${ }^{98}$ Protestants, summarily dismissed as "heretics", also frequently earned offensive verbal characteristics; in addition, they were the only people in these stories who occasionally converted to the Orthodox faith and stood in need of catechetical instruction. ${ }^{99}$ Roman Catholics simply repented--and remained Catholic. Mohyla's miracle tales thus convey the sense of an affinity of Orthodox and Catholic beliefs as much as they emphasize the absence of any similarity of belief between Orthodoxy and Protestantism. ${ }^{100}$

${ }^{97}$ Arkhiv IuZR, I, 7, p. 72.

${ }^{98}$ Arkhiv IuZR, I, 7, p. 114.

${ }^{99}$ Arkhiv IuZR, I, 7, pp. 68-69.

${ }^{100}$ For an example of Mohyla's anti-Protestant philippics elsewhere see Arkhiv IuZR, I, 8, pp. 400-401. On his liking for Catholic devotional literature see Liudmila V. Charipova, "Peter Mohyla's Translation of The Imitation of Christ", Historical Journal, 46 (2003), 237-61. 
The start of the regeneration of the Ruthenian Church, spearheaded by Mohyla's visionary leadership, dates back to the foundation in 1632 of the Kiev College, the first institution of its kind in the Orthodox world. For nearly half a century Orthodox religious activists had been calling for the provision of educational facilities for Ruthenian youths on a par with the schools run by other Christian confessions. But even the best available schools offered curricula that did not go beyond the elementary level and focused on giving instruction to pupils in the "Slavonic and Greek letters". This kind of schooling left their graduates ill equipped both for quotidian proceedings in the secular courts and provincial diets of the Commonwealth, which relied as much on Latin as on Polish, and for resisting skilful Catholic and Evangelical proselytizing. ${ }^{101}$ There were no seminaries for the Orthodox clergy, and the universally poor level of education among Orthodox parish priests made them a regular laughing stock for rival confessions. Mohyla's college was based on the failing school of the Kiev Epiphany Confraternity, which he took over and staffed with his associates. Like him, they had received humanist education in Jesuit schools in Poland-Lithuania and abroad. Unlike the previous generation of Orthodox literati, they were Latin scholars of considerable repute. The college's Latin-based curriculum embraced the seven liberal arts and was designed to incorporate the teaching of philosophy and theology at a later stage. Boys of all social conditions were encouraged to attend, both with a view to receiving general education and in the hope that the best students would subsequently choose a clerical career. Through its alumni the Kiev College would prove instrumental for the revival of the Orthodox Church in Ruthenia and beyond, in places like Muscovy, Moldavia and the Balkans in the $17^{\text {th }}$ and $18^{\text {th }}$ centuries.

${ }^{101}$ See Arkhiv IuZR, I, 8, p. 444; ibid., I, 9 (Kiev, 1898), pp. 375-376. 
Mohyla's appointment as the Metropolitan of Kiev (1633-1646) was part of the legal restoration of the Orthodox Church in the Commonwealth, achieved as a result of an understanding reached between the Orthodox political lobby and the crown following the death in 1632 of the intolerant Sigismund III. According to the "Articles of Peace", drawn up by the Commission for the Reconciliation of the Eastern Church, Orthodox bishops, illegally consecrated in 1620 , were to be replaced with a new church hierarchy that would have full royal sanction. Following the protest of the Greek Catholic Metropolitan Joseph Rutskii (1613-1637) to Rome, Pope Urban VIII dispatched letters to Prince Wladyslaw, Sigismund's son and the chief candidate for the Polish throne, and the leaders of Catholic nobility in the Commonwealth, insisting that the "Articles of Peace" not be ratified. But the Commonwealth's situation, both domestic and international, made the Pope's demand impossible to comply with. The diet that met for the coronation of Wladyslaw IV on 6 February 1633 agreed to approve the "Articles", although it stopped short of formal ratification. ${ }^{102}$

The centralized model of Orthodox ecclesiastical structure introduced by Mohyla incorporated both old and new elements brought together under the umbrella of metropolitan authority. ${ }^{103}$ In another pioneering development, the creation in 1634-1635 of the Ecclesiastical Consistory (metropolitan's court), based on the Roman Catholic model and subordinate to the metropolitan, finally removed Orthodox clergy from the

\footnotetext{
${ }^{102}$ Francis Thomson, "Peter Mogila's Ecclesiastical Reforms and the Ukrainian Contribution to Russian Culture: A Critique of Georges Florovsky's Theory of the Pseudomorphosis of Orthodoxy", Slavica Gandensia, 20 (1993), p. 82.

${ }^{103}$ Zhukovs'kyi, Petro Mohyla i pytannia iednosty tserkov, p. 97.
} 
jurisdiction of the civil authorities. ${ }^{104}$ Apart from creating a system of church administration supported by the appointment of clerical officials, Mohyla revived the existing parallel structure of ecclesiastical authority in the form of annual diocesan synods. Parish priests were expected to attend, report on their work, be examined in matters of clerical competence and the canonicity of their appointment, and receive advice on complex questions of religious practice. ${ }^{105}$ Anyone who had remarried, was "arrogant, greedy, immoral, lustful, a drunkard, a speculator or a moneylender, not skilled in the Scriptures or, worse still, unable to read them properly, and those who did not confess twelve times a year" were barred from priesthood. ${ }^{106}$

Part of Mohyla's drive toward a centralized church administration focused on curtailing exclusive privileges of lay confraternities, especially those that claimed exemption from local episcopal jurisdiction. In a move reminiscent of the resolutions of the bishops-led 1591 synod of Brest, Mohyla banned the confraternities from all direct contacts with the Eastern patriarchs and warned that any kind of privilege received in circumvention of the metropolitan power would be invalid. ${ }^{107}$ Blanket censorship of

${ }^{104}$ Zhukovs'kyi, Petro Mohyla i pytannia iednosty tserkov, p. 99.

${ }^{105}$ Zhukovs'kyi, Petro Mohyla i pytannia iednosty tserkov, pp. 97-98; on the Catholic diocesan chapters as a prototype of the metropolitan consistory see E. Kryzhanovskii, "Kievskaia dukhovnaia konsistoriia v XVIII veke”, idem, Sobranie sochinenii, 1 (Kiev, 1890), pp. 441-443.

${ }^{106}$ Cited in Stepan Golubev, Kievskii mitropolit Petr Mogila i ego spodvizhniki: Opyt istoricheskogo issledovaniia, 2 (Kiev, 1898), p. 484.

${ }^{107}$ See Appendices, Golubev, Kievskii mitropolit Petr Mogila i ego spodvizhniki, 1 (Kiev, 1883), p. 557. 
religious publications was introduced to prevent the multiplication and distribution of imperfect copies and corrupted texts. Minor skirmishes with confraternities still occurred over publishing rights, appeals to Constantinople, or the right of election of clerical staff to serve in confraternity-run religious institutions. ${ }^{108}$ However, Mohyla's keen political sense and long-standing ties of patronage and charity between his family and the Lviv Confraternity in particular, helped to maintain good working relations. The foundation of the Kiev College reconciled Mohyla's modernizing drive for a Latin-based Orthodox education with the cultural aims of confraternities. Moreover, it became a major victory that marked the beginning of a virtual clerical monopoly in pedagogy. ${ }^{109}$ Combined with the strengthening of the church hierarchy, this process finally put paid to the centrality of lay confraternities in religious and cultural matters, confining their activity to the upkeep of church buildings and other local concerns. It is also possible that the confraternities had learned the hard way the ruinous price a politically weak church had to pay for a running war between the laity and the episcopate.

On the whole, the administrative changes introduced by Mohyla, the cautious but decisive way in which he dealt with confraternities, and his efforts to minimize the damage caused by the irregularities of lay patronage over clerical benefices all bear the trademark of the bishops' reforms as they had been conceived in 1590-1595. His

${ }^{108}$ Appendices, Golubev, Kievskii mitropolit Petr Mogila, 2, pp. 86-91, 176-79, 182-86, 249-50; also see Zhukovs'kyi, Petro Mohyla i pytannia iednosty tserkov, pp. 100-101. ${ }^{109}$ See Alexander Sydorenko, The Kievan Academy in the Seventeenth Century (Ottawa, 1977), pp. 29-30. 
overhaul of the Metropolitanate of Kiev may thus be regarded as the realization of the top-down programme of change, whose completion had eluded his predecessors.

Much of the crisis within the Eastern Church was attributable to the absence of a universally accepted statement of Orthodox belief. The importance of such confessional statements for the creation of defensible religious identities in early modern Europe has long been axiomatic. Possibly mindful of the divisiveness of larger councils involving lay representation, during the thirteen years of his rule as the metropolitan Mohyla convened only one synod of the Ruthenian Church, called in Kiev in 1640 to discuss his Orthodox confession. Among its principal sources were the Tridentine Catechismus Romanus (first published in Rome in 1566) and the Summa doctrinae Christianae by the Jesuit Peter Canisius (first published in Vienna in 1554). ${ }^{110}$ A Polish edition of the Catechismus Romanus is found among the surviving books from Mohyla's private library. ${ }^{11}$ Approved by the Kievan synod, Mohyla's confession needed authorization as canonical received from the Eastern patriarchs, and in 1642 its Latin version was submitted to the

${ }^{110}$ Antoine Malvy et Marcel Viller, eds., La confession Orthodoxe de Pierre Moghila, Métropolite de Kiev (Paris, 1927), pp. XCVII-CV; Thomson, “Peter Mogila’s Ecclesiastical Reforms", p. 97. The historian and theologian Ievstafii Cherviakovskii dedicated a very detailed study to a comparison of Mohyla's confession with the Catechismus Romanus: Ievstafii Cherviakovskii, Rimskii katekhizis i pravoslavnoe ispovedanie Petra Mogily: Opyt kritiko-bibliograficheskogo issledovaniia (Warsaw, 1889).

${ }^{111}$ Charipova, Latin Books and the Eastern Orthodox Clerical Elite, p. 187. 
synod in Iaşi, Moldavia, which also condemned Lukaris's "Calvinist" catechism. ${ }^{112}$ There the patriarchal representative Meletius Syrigos translated the text into Greek and revised several passages he found offensively Roman Catholic; forwarded to Contantinople, this amended version was declared canonical in $1643 .{ }^{113}$ Shorter versions of Mohyla's catechism in Polish and Ruthenian, which ignored Syrigos's corrections, were issued in Kiev in 1645 (and reprinted in Moscow in 1649). Syrigos's Greek version was published in Amsterdam in 1666, its Romanian translation--in 1691, and a version in Church Slavonic appeared in Moscow in 1696. ${ }^{114}$ In Steven Runciman's estimation, Mohyla's confession represented "the first attempt since the days of John of Damascus to give precision to the main beliefs of the Church; and it [tried] to answer questions that had recently arisen during discussions with the Western Churches". ${ }^{115}$

Mohyla's last project, the Euchologion, an extensive manual of Orthodox rites, published shortly before his death in 1646 , also displayed strong Catholic influences. ${ }^{116}$

${ }^{112}$ See Malvy et Viller, La confession Orthodoxe de Pierre Moghila, p. L; Thomson, “Peter Mogila’s Ecclesiastical Reforms", p. 93.

${ }^{113}$ Zhukovs"kyi, Petro Mohyla i pytannia iednosty tserkov, p. 154; Thomson, "Peter Mogila's Ecclesiastical Reforms”, p. 96.

${ }^{114}$ Dragos Mîrşanu, "Old News Concerning Peter Mogila's Orthodox Confession: The First Edition Revisited”, Archæus, 10 (2006), 273-86; Zhukovs'kyi, Petro Mohyla i pytannia iednosty tserkov, p. 156.

${ }^{115}$ Steven Runciman, The Great Church in Captivity (Cambridge, Eng., 1968), p. 344.

${ }^{116}$ A. Wenger, "Les influences du Rituel de Paul V sur le Trebnik de Pierre Moghila", Revue des sciences religieuses, Volume hors série: Mélanges en l'honneur de Monseigneur Michel Andrieu (1956), 477-99; Arkadii Zhukovs'kyi, “Analiza trebnyka 
Thirty-seven of the 126 rites included in it were direct adaptations of Roman Catholic service-books, such as the Rituale Romanum of Pope Paul V (Rome, 1615). ${ }^{117}$ The confession of faith for Protestant converts received into the Orthodox Church was an "emended translation of the [1564] Professio fidei Tridentina ... and included the doctrines of transubstantiation and a third intermediate state for dead souls distinct from heaven or hell". ${ }^{118}$ Superficially, Mohyla's method of collating the fundamentals of Eastern Christianity with Catholic practices served a dual purpose of introducing elements wholly lacking in Orthodox usage and substituting Catholic practices for already existing Orthodox rites that had become corrupted. By extension (and also, without doubt, by design) this emphasis on the proximity of Catholic and Orthodox positions postulated the distance between Orthodox and Protestant.

By way of conclusion we may join Meletius Smotritskii in his query addressed in 1629 to the "Calvinist" patriarch of Constantinople Cyril Lukaris: "in all the abovenamed articles of faith, are we in agreement with the Romans or the Evangelicals, or do we adhere to and confess some third, middle thing"? ${ }^{119}$ Whether asked in good faith or

Petra Mohyly", idem (ed.), Trebnyk Petra Mohyly, perevydannia z oryhinalu, shcho poiavyvsia u drukarni Kyievo-Pechers'koï Lavry 16 hrudnia 1646 r. (Canberra, 1988), pp. 30-32.

${ }^{117}$ Zhukovs'kyi, Petro Mohyla i pytannia iednosty tserkov, p. 164; Thomson, "Peter Mogila's Ecclesiastical Reforms”, p. 87.

${ }^{118}$ Thomson, "Peter Mogila's Ecclesiastical Reforms", p. 90; cf. Trebnyk mytropolyta Petra Mohyly [facsimile edition] (Kharkiv, 2007), 1, pp. 130-131, 137. ${ }^{119}$ Collected Works of Meletij Smotryc'kyj, intr. D. Frick, Harvard Library of Early Ukrainian Literature: Texts 1 (Cambridge, Mass., 1987), p. 684. 
not, this is a question of fundamental importance. Certainly encompassing Smotritskii's own chequered experience, it similarly applies to most other ecclesiastical figures in the Orthodox world who concerned themselves with trying to shape the future of their church in the 1580s-1640s: the reform-minded patriarchs, the unionizing bishops, and the Latin scholars of Mohyla’s Kievan milieu. David Frick attributes Smotritskii’s particular difficulty in answering this question to his inability to produce a positive statement of Orthodox belief. ${ }^{120}$ But Smotritskii was not alone in this predicament, since the absence of lapidary doctrinal certainties, which had always distinguished the Eastern Church from its Roman Catholic counterpart, revealed Orthodox difficulty with holding its own in the debates of the Confessional Age. While allowing for a degree of dialectical flexibility, habitual dislike for prescriptive regulation locked the development of Orthodox theological thought into a kind of a time-warp by making them dependent for guidance and inspiration on the only clear-cut set of rules there was: the decrees and canons of the first seven ecumenical councils. This may explain why $16^{\text {th }}$ - and $17^{\text {th }}$-century Orthodox commentators kept describing Protestant beliefs in terms of their disregard for church tradition, corruption or rejection of Marian devotion, Antitrinitarianism and iconoclastic excesses, but held Roman Catholicism to be free from these faults. ${ }^{121}$ Perceptibly nearperfect political allies in the struggle for religious toleration, Orthodox and Protestants

${ }^{120}$ Frick, Meletij Smotryc'kyj, p. 209.

${ }^{121}$ Dashkevich, "Odin iz pamiatnikov religioznoi polemiki XVI veka”, p. 199; Arkhiv $I u Z R, I, 8$, p. 18; cf. the description of the rite of receiving an "Arian" (i. e. a Unitarian or Antitrinitarian) to the Orthodox Church in Mohyla's ritual: Trebnyk mytropolyta Petra Mohyly, 1, pp. 119-35. 
remained too far apart in doctrinal terms to form a lasting partnership outside the debating chamber of the diet. ${ }^{122}$

"History happens accidentally and through the power of specific places and people". ${ }^{123}$ Like Borges's "garden of forking paths", at its inception Orthodox reform held the potentiality for several futures. In the last analysis, the protagonists of religious renewal on all sides strove to achieve the same objectives, albeit by different means: to free the church of abuses, to raise its political and cultural status in the Commonwealth society, and to fill the gaps they viewed as deleterious to its progress. Mohyla's death in December 1646 and the outbreak of the Cossack Wars in 1648, in which religion proved to be the most explosive ingredient, meant that the locus of Orthodox reform had to move away from conflict-torn Poland-Lithuania.

Liudmila V. Charipova is a lecturer in early modern history at the University of Nottingham, UK. She is the author of Latin Books and the Eastern Orthodox Clerical Elite in Kiev, 1632-1780 (Manchester, 2006), and a number of articles on the intellectual origins of educational and church reforms in the East Slavic lands in the $17^{\text {th }}$ and $18^{\text {th }}$ centuries.

${ }^{122}$ Bortnik, "Problem tolerancji w prawosławnej myśli teologicznej”, pp. 168-69. For a thorough analysis of cooperation between Orthodox and Protestant in the political sphere see Tomasz Kempa, Wobec kontrreformacji: Protestanci i prawosławni w obronie swobód wyznaniowych w Rzeczypospolitej w końcu XVI i v pierwszej połowie XVII wieku (Toruń, 2007).

${ }^{123}$ Ulinka Rublack, Reformation Europe (Cambridge, Eng., 2005), p. 61. 


\section{SELECT BIBLIOGRAPHY}

- Liudmila V. Charipova, "Peter Mohyla's Translation of The Imitation of Christ", Historical Journal, 46 (2003), 237-261

- Liudmila V. Charipova, Latin Books and the Eastern Orthodox Clerical Elite in Kiev, 1632-1780 (Manchester, 2006)

- Teresa Chynczewska-Hennel, "The Political, Social, and National Thought of the Ukrainian Higher Clergy, 1569-1700”, Harvard Ukrainian Studies, 24 (20022003), $97-152$

- Mikhail V. Dmitriev, "Western Christianity and Eastern Orthodoxy", Reform and Expansion, ed. R. Po-Chia Hsia, The Cambridge History of Christianity 6 (Cambridge, Eng., 2007), pp. 321-342

- Mikhail V. Dmitriev, "Conflict and Concord in Early Modern Poland: Catholics and Orthodox at the Union of Brest", Diversity and Dissent: Negotiating Religious Difference in Central Europe, 1500-1800, eds Howard Loutan, Gary B. Cohen, and Franz A.J. Szabo (New York and Oxford, 2011), pp. 114-136

- Borys A. Gudziak, Crisis and Reform: The Kyivan Metropolitanate, the Patriarchate of Constantinople, and the Genesis of the Union of Brest, Harvard series in Ukrainian studies (Cambridge, Mass., 1998)

- David A. Frick, Meletij Smotryc'kyj (Cambridge, Mass., 1995) 
- David A. Frick, “Misrepresentations, Misunderstandings, and Silences: Problems of Seventeenth-Century Ruthenian and Muscovite Cultural History”, Religion and Culture in Early Modern Russia and Ukraine, eds. Samuel H. Baron and Nancy Shields Kollmann (De Kalb, Ill., 1997), pp. 149-168

- Iaroslav Isaievych, Voluntary Brotherhood: Confraternities of Laymen in Early Modern Ukraine (Edmonton, Toronto, 2006)

- Paschalis M. Kitromilides, “Orthodoxy and the West: Reformation to Enlightenment”, Eastern Christianity, ed. Michael Angold, The Cambridge history of Christianity 5 (Cambridge, Eng., 2006), pp. 187-209

- Frank E. Sysyn, 'Ukrainian Social Tensions before the Khmel'nyts'kyi Uprising', Religion and Culture in Early Modern Russia and Ukraine, eds. Baron and Kollmann, pp. 52-70

- Francis J. Thomson, “Peter Mogila’s Ecclesiastical Reforms and the Ukrainian Contribution to Russian Culture: A Critique of Georges Florovsky's Theory of the Pseudomorphosis of Orthodoxy", Slavica Gandensia, 20 (1993), 67-119

- George Williams, "Protestants in the Ukraine during the Period of the PolishLithuanian Commonwealth", Harvard Ukrainian Studies, 2 (1978), 41-72, 184210 